\title{
Incentivized Time Preferences, Level of Education in a Household and Financial Literacy: Laboratory
} Evidence

\author{
Calvin Mudzingiri1*, John W. Muteba Mwamba², Jacobus Nicolaas Keyser ${ }^{3}$ \\ ${ }^{1}$ University of the Free State- Qwaqwa Campus, Phuthaditjhaba, South Africa \\ ${ }^{2}$ School of Economics, University of Johannesburg, South Africa \\ ${ }^{3}$ University of the Free State, South Africa \\ *mudzingiric@ufs.ac.za, johnmu@uj.ac.za, keyserjn@ufs.ac.za
}

\begin{abstract}
This study investigates the impact of financial literacy, level of education in a household and gender differences on time preferences of students at a university in South Africa. The study relies on a convenient sample of $(\mathrm{N}=85$, female $=48 \%)$ pursuing a financial literacy course. The study uses a questionnaire, a financial literacy test and a simple binary choice experimental game that elicited individual time discount rate to gather data. Ten percent of the participants were paid (in South African rands) for their time preference choices by way of quota random sampling. Female university students' individual time discount rate was found to be on average higher than that of their male counterparts, indicating that female university students are generally impatient, especially those with low levels of financial literacy. Our results (using a Negative Binomial Regression analysis and Ordinary Least Squares regression analysis) show that time preferences of university students aresignificantly influenced by highest level of education in the household. The OLS regression model shows that financial literacy, measured using financial literacy test, significantly influence time preferences for all subjects. The study concluded that patience levels among male university students increase as financial literacy increases. Gender, income, age and family size significantly influence time preferences of university students. Highest level of education in a household, financial literacy and gender differences have a bearing on individual time preferences.
\end{abstract}

Keywords: Time preferences, financial literacy, education, individual discount rate, gender, impatient, Experiment

\section{Introduction}

Time preferences can reveal one's levels of patience and self-control, attributes which are critical in making financial investments and choices. The pleasure of consuming goods immediately as opposed to the discomfort of future consumption is mainly influenced by the circumstances in which decision-makers find themselves (DellaVigna, 2009; Frederick, Loewenstein, \& O'donoghue, 2002; Loewenstein, Read, \& Baumeister, 2003; Rae \& Mixter, 1905). Research evidence suggests that individuals' time preferences are highly correlated with financial literacy-information acquisition, job search for a long period, earning of higher wages, preparation to take up contingency measures to improve future welfare and generally better financial outcomes (DellaVigna, 2009; Meier \& Sprenger, 2013).Time preferences have been used to explain economic concepts such as credit card take up, life cycle savings, retirement savings, procrastination, homework and deadlines as well as perseverance by individuals (DellaVigna, 2009). Aspects of time preferences such as self-control and patience determine whether individuals make choices immediately, in the near future, or in the distant future. On the other hand, financial literacy, according to Huston (2010), relates to measuring how well an individual can understand as well as use personal finance-related information. This implies that for one to be financially literate, one should be able to use financial knowledge to improve one's welfare. This statement is further backed by Gallery, Newton and Palm (2011) and Schagen and Lines (1996) who consider financial literacy to be the ability to make informed judgments and take effective decisions regarding the use and management of money.

Both definitions of financial literacy suggest a variation in time preferences among people with different levels of financial literacy. The differences in welfare outcomes of people across financial levels could be explained by variations in time preferences. In reality, choices made at a given moment to accrue benefits in the present or future, are aimed at maximizing one's utility; therefore, one's financial knowledge might be an important factor. In addition, time preferences are sometimes strongly associated with an individual's cognitive ability (Frederick, 2005). Cognitive ability plays an important role in helping individuals achieve beneficial outcomes (Banks, o'Dea, \& Oldfield, 2010). Further, presenting incentives in the form of actual 
money payment on the choices made by individuals can be seen as the setting up of a practical life situation conducive to displaying true time preference behaviour. This study investigates the impact of financial literacy, highest level of education in a household and gender differences on time preferences of university students at a university in South Africa. The discrete and non-negative value nature of time discount rates allows the study to use theNegative Binomial regression method to analyse data (Hilmer \& Hilmer , 2014). We also constructed a variable Time Preference index (TPI) and regressed a set of Ordinary Least Squares models in our investigation (Németh, 2014). A total convenient sample of 85 university students took part in a financial literacy test and a time preference experimental game that was included in a questionnaire. The simple binary choice time preference experimental game used tokens which were allocated over time and summed into a time budget (TB), making the design an inter temporal choice framework( Andreoni, Kuhn, \& Sprenger, 2015; Angerer, Lergetporer, Glätzle-Rützler, \& Sutter, 2015). Students that scored a mark above the average in the financial literacy test were categorized as the high financial literacy group, whereas those that scored a mark below average represented the low financial literacy group. Ten percent of the participants were randomly selected and paid the actual amounts of their choices using quota random sampling and according to the instructions in the time preference game. The quota random sampling incentivized system allowed all participants a fair and equal chance of being selected for payment.

The study also explored whether the state of world where university students survive in, influenced their time preferences. The state of the individual's world may include gender orientation and family status among others. In a society which participates in inter temporal choice decision making, university students are an important component mainly because of their level of financial literacy, therefore, it is critical to understand the determinants of their time preferences. In addition, students are the most logical next entrants into the job market where saving and investment decisions are equally vital. The possibility of time preferences being influenced by financial literacy and highest level of education in a household is significant in two ways. First, the impact of financial literacy on individual time preferences may sum up into market outcomes which might help authorities to design policies that improve welfare of citizens. Secondly, the impact of highest level of education in a household on university students' time preferences can explain the intergenerational education spill over. Further, understanding gender differences in time preference choices might assist in designing interventions necessary to reduce disparities. A number of studies have explored the level of financial literacy across gender, economic status, social status and area of specialization(Batty, Collins, \& Odders-White, 2015;Lusardi, Mitchell, \& Curto, 2010; Shambare \& Rugimbana, 2012; Oanea \& Dornean, 2012; Mandell, 2008). However, very little information is available on the interaction between financial literacy level, gender differences and time discount rate as a measure of time preferences. The fact that financial literacy attainment yields better welfare outcomes cannot be doubted (Becchetti, Caiazza, \& Coviello, 2013; Tang \& Peter, 2015; Sayinzoga, Bulte, \& Lensink, 2016). What is not clear, however, is how financial literacy affects one's level of patience or impatience, which is measured by one's individual time discount rate. The level of patience (or impatience) allows individuals to gainfully use financial literacy acquired to improve current and future welfare(Carlin \& Robinson, 2010).

This study follows researches by Frederick (2005), Benjamin, Brown and Shapiro (2013) and Parker and Fischhoff (2005). Fredrick tested time preferences of subjects using a cognitive reflection test (CRT) and concluded that there are time preferences variations across gender. Benjamin et al (2013) concluded that Chilean high school students with a high maths score were more patient while Parker and Fischoff (2005) found out that vocabulary proficient scholars were more likely to be patient. Our results are mixed; female university students were more likely to be impatient especially those with lower levels of financial literacy while on the other hand, increase in financial literacy levels among male students also increased patience. There is evidence that show that the highest level of education in a household influences time preference of university students. The OLS regression model shows that financial literacy significantly influences time preferences of all participants and male participants in particular. Our study can also be compared with studies by Meier and Sprenger (2013) as well as Sabri et al. (2010). The next section presents a review of literature, followed by a discussion of the methodology, data analysis and presentation of results. The final section provides the conclusion of the study. 


\section{Literature Review}

Financial behaviour is known to be determined by financial knowledge, perceptions, norms, and attitudes(Kennedy, 2013). Important financial attitudes that help economic agents to maximise on their financial behaviour are time preferences, which is a process of making inter temporal choices. The quest to understand what drives time preferences has been a subject of debate to researchers(Capuano \& Ramsay, 2011; Hoch \& Loewenstein, 1991; Loewenstein \& Thaler, 1989;Frederick, Loewenstein, \& O'donoghue, 2002). Although individual time discount rate is used to measure time preferences, a number of factors are known to influence time preferences; namely, habit formation, affection, anticipatory utility and visceral influences(Frederick et al., 2002). Neoclassical economics holds that exhibiting an optimal behaviour is an aspect of rational choice (Mas-Colell, Whinston, \& Green, 1995). Predictable, yet irrational behaviour exhibited by consumers is mainly driven by knowledge and psychological processes that create mental "shortcuts" as well as biases (Smith \& Barboza, 2014). Beside neoclassical suggestions, human beings have exhibited time-inconsistent behaviour, which is an aspect of irrationality (Hoch \&Loewenstein, 1991; Loewenstein \& Thaler, 1989; Imrohoroglu, Imrohoroglu, \& Joines, 2003). Students' social upbringing, cognitive ability, circumstances and the surrounding environment can play an important role in determining their time preferences(Frederick, 2005).Preferences in general influence supply and demand of goods, a fact that has incentivized researchers to gain greater insight into how preferences are formulated (Ariely, Loewenstein, \& Prelec, 2003). In addition, poorly enforced property rights increase impatience which is an aspect of time preferences (Epper, Fehr-Duda, \& Bruhin, 2009). Measuring time preferences has generally presented challenges to researchers and no single method is absolved of errors in measuring discount rates (Loewenstein et al., 2003). Although research contents that inter temporal time preferences exhibit hyperbolic discount rates, that is, discount rates tend to be lower as time frame for rewards gets longer (Epper, Fehr-Duda \& Bruhin, 2009), a number of researchers have tended to use laboratory experiments to explain time preferences in real life situations (Ariely \& Wertenbroch, 2002; Ausubel, 1999). Their findings reveal that individuals make time preference choices that maximize their utility and resemble real life behaviour.

There has also been a concerted effort to test whether laboratory experiment findings explain real behaviour of subjects in the practical world. The general consensus is that the measured time preferences lack the scope to explain actual human behaviour (Chabris, Laibson, Morris, Schuldt, \& Taubinsky, 2008). However, a number of researchers concluded that there is a close relationship between experimental research findings and true human time preference choices (Benzion, Rapoport, \& Yagil, 1989; Charness, Gneezy, \& Imas, 2013; Meier \& Sprenger, 2013). A research project in the district of Georgia in the US in 2008 concluded that dropouts and referrals were positively correlated with impatient behaviour (Castillo, Ferraro, Jordan, \& Petrie, 2011). The findings are, however, inconclusive in that the research project could not identify precisely what drives individual and group time preferences. On the other hand, financial literacy has been hailed for improving welfare of individuals and society. A study on elementary school students by Batty et al. (2015) found that financial education impacted attitudes. The findings indicate that one's level of financial literacy influences how one makes inter temporal choices and that financial knowledge influences time preferences. In addition to their findings, students that were exposed to financial literacy were able to save and were financially savvy. Another aspect that has been found to be important in moulding inter temporal choices is family background. In a study by (Sabri, MacDonald, Hira, \& Masud, 2010) carried out in Malaysia, students that received financial literacy from their parents exhibited better financial outcomes and were more likely to save money. This suggests that knowledge within a household plays a pivotal role in shaping time preferences.

Time preferences represent an aspect of inter temporal choice and researchers have investigated how it is impacted by financial literacy level as well as gender orientation. In short, time preferences reveal one's choices over time while financial literacy has more to do with financial knowledge and the ability to apply financial knowledge (Güth, 2004; Huston, 2010). The direction of causality between financial literacy and time preferences seems difficult to tell, however, evidence suggests that interaction of the two influences life outcomes(Benjamin, Brown \& Shapiro, 2013). Meir and Sprenger (2013) conducted an incentivized multiple price list experiment on individuals participating in a volunteer income tax assistance (VITA) credit counselling programme and concluded that participants in the VITA program had a higher discount rate. 
Research evidence suggests that there are variations in time preferences across gender. For example, a research study investigating time preferences of high school students carried by Castillo et al. (2011) concluded that boys compared to girls had a higher discount rate - suggesting impatience amongst boys. Gender differences are mainly driven by variation in preferences (Croson \& Gneezy, 2009). An increased number of literature on risk preferences found out that women are more risk averse compared to men (Charness \& Gneezy, 2012; Eckel \& Grossman, 2008; Powell \& Ansic, 1997). Aside observing differences in risk preferences across gender, there is also evidence of variation in time preferences by gender and race (Norum, 2008; Adan \& Natale, 2002). Married women were concluded to be investing less in common stock than married men (Bajtelsmit, 1999). However, there are some studies that could not conclude variation in time preferences across gender(Kim, Dueker, Hasher, \& Goldstein, 2002). In a research study comparing risk and time preferences among students in the USA, no differences were found across gender (Bernheim, Garrett, \& Maki, 2001). Evidence from previous work on time preferences and education remain inconclusive.

Financial literacy is a form of education on financial concepts and requires cognitive prowess to master. Research has concluded a correlation between education and time preferences (Van der Pol, 2011;Lawrance, 1991; Fuchs, 1980). Van der Pol (2011) and Lawrance (1991) observed that time preferences tend to decrease as the level of education increases. Their studies were confined to health and poverty but did not focus on financial literacy. Financial literacy level may or may not vary across university students in general. There is evidence of variation of financial literacy level by gender, degree being pursued, family background among others (Cull \& Whitton, 2011; Lusardi, Mitchell \& Curto, 2010;Chen \& Volpe, 1998). Chen and Volpe (1998) found out that female students were less financially literate compared to their male counterparts. In a 2010 study in Romania, it was concluded that male university students had a higher level of financial literacy compared to females (Oanea \& Dornean, 2012). If there is a correlation between time preferences and financial literacy then, this could partially explain variation in life outcomes. On the other hand, there are studies that conclude absence of differences in financial literacy especially for university students (Wagland \& Taylor, 2009). Little research has been carried out to investigate the impact of financial literacy level on time preferences. More so, it is not clear whether there is reverse causality between financial literacy and time preferences. There is need to understand factors that influence time preferences of individuals given the fact that they play an important role in determining life outcomes. More needs to be explored with regard to time preferences and gender differences.

\section{Methodology}

The study used a modified stylized standard model version by Rabin (2002) given below, to explain how individuals make choices over time.

$\max _{x_{i \in X_{i}}^{t}} \sum_{t=0}^{\infty} \delta^{t} \sum_{s_{t \in S_{t}}} p\left(S_{t}\right) U\left(x_{i}^{t} / S_{t}\right)$

where, individual university student $i$ at time $t$ maximizes expected utility subject to probability distribution $p(s)$ of the states of the world $s \in S^{\prime \prime}$ (DellaVigna, 2009; Rabin, 2002). The utility function $U(x / s)$ is defined over pay-off of the experimental game $x_{i}^{t}$ of subject (i) over one's state of the world $(s)$ and future utility is discounted with a discount factor $\delta$ for naiveté assumed to be time consistent. $S$, the state of the university student's world explained by financial literacy level, highest level of education in a household, financial literacy perceptions, student characteristics and the demographic information. In the study, the minimum discount rate is set at 0 and the maximum discount rate is set at 5.The discount factor $\delta$ is calculated from the choices made by the subjects given as (columnA/column B), where column $\mathrm{A}$ is the present time pay-off received after 2 weeks and column B is delayed consumption paid after 6 weeks(Meier \& Sprenger, 2013).

To deal with present time bias, the initial payment is paid in the future period(Alan \& Ertac, 2015) such that:

$b_{1}+\beta \delta b_{2} \geq 0$.

where $b_{1}$ is pay-off in 2 weeks and $b_{2}$ is pay-off in 6 weeks. $\beta$ represents unobservable self-control or patience problems and $\delta$ is the future utility discount rate. We adopted a simplified model used by Epper et al.(2009) and (Frederick, 2005), since our data could not capture risk parameters, we did not include the risk value. We formulated aNegative Binomial regression model as follows:

$\delta($ timediscountrate $)=f($ financial literacy score, financial literacy perceptions, age, highest level of education in a household, number of family members in a household, income). 
Our dependent variables time discount rate is discrete, the variance and mean are significantly different from each other which made a Negative Binomial regression model suitable for analysing our data instead of a Poisson regression model (Hilmer \& Hilmer, 2014). We tested the Likelihood-ratio test of alpha for the Negative Binomial regression model and the Poisson regression model as a way of determining the appropriate model to use for our data analysis. Our results show a likelihood-ratio test of Alpha $=0$ : chibar2(01) $=135.99$ Pro $>=$ chibar2 $=0.000$, confirming over dispersion which allowed us to use the Negative Binomial regression model in our analysis. In addition, university students' preference choices were nonnegative ranging between 0 and 5. Financial literacy is measured using the mark scored in the financial literacy test written before students are taught financial literacy concepts. This is the variable that measures the financial literacy or knowledge level of the university students. A number of studies have used financial literacy test to measure financial knowledge (LaBorde, Mottner, \& Whalley, 2013; Mandell, 2008; Sayinzoga et al., 2016). Financial knowledge, perceptions and norms play a vital role in shaping financial attitudes and behaviour (Ajzen, 2011).To assess financial literacy perceptions, we asked the following three questions adopted from Lusardi et al., (2010)

i. On a scale from 1 to 7 , where 1 means very low and 7 means very high, how would you assess your overall financial knowledge?

ii. Please give your answer on a scale of 1 to 7, where 1 = "Strongly Disagree," 7 = "Strongly Agree,"

a) I am good at dealing with day-to-day financial matters, such as checking accounts, credit and debit cards, and tracking expenses

b) I am pretty good at math

A single variable of perceptions was predicted using factor analysis. Self-reported age, highest level of education in the family, family size and individual income are some of the variables that were used. The highest level of education in the family was used as a proxy for family status, because number of education years has been found to be positively correlated with higher levels of income(Argent, Finn, Leibbrandt, \& Woolard, 2009). A question in our questionnaire asked respondents to indicate the highest level of education in their households excluding themselves. The age of a respondents is normally associated with experience, as one gets older, bank of knowledge grows until retirement (Lusardi \& Mitchell, 2005). Income is measured using self-reported cash and cash equivalence that university students were holding during the time of the study. The respondents also indicated the numbers of family members in their households. Family size, income and age are some of the variables that have been concluded to be influential in shaping time preferences in some studies(Andersen, Harrison, Lau, \& Rutström, 2006;Meier \& Sprenger, 2013).We further constructed variable time preference index (TPI) and ran an Ordinary least squares regression model on same variables indicated above. TPI represents time preferences choice over financial literacy.

$T P I=\frac{\text { individualtimediscountrate }}{\text { financialliteracytestscore }}$

Variable TPI is a continuous variable which made it possible for us to analyse our data using an ordinary least squares regression model.

Time Preferences: Eliciting Individual Discount Rates: A simple binary choice time preference game was used to collect students' individual discount rates. In the time preference game, the subjects were asked to allocate five tokens between two periods; that is, after 2 weeks or after 6 weeks- resembling an investment or savings venture. The instruction for the experiment is as follows (Giné, Goldberg, Silverman, \& Yang, 2011; Angerer et al., 2015):

"You are allocated 5 tokens. If you place the token in column A you will be paid R20 per token paid after 2 weeks. If you place the token in column B you will be paid R25 per token paid after 6 weeks. To receive payment for your choices you should pick a winning ticket from a raffle".

The choice for the price paid for each token is based on the interest levied on creditors by local loan sharks (credit providers) 'Mashonisas', who charge an interest between $15 \%$ to $50 \%$ per month. To deal with the present time bias in the subject's choices a front end delay payment was used (Andersen, Harrison, Lau, \& Rutström, 2008). Choices for column A were paid after 2 weeks (which resembled a present time pay-off or Smaller Sooner), whereas choices for column B were paid after 6 weeks(a future period pay-off or larger later) (Andreoni \& Sprenger, 2012). To select the winners, the researcher used quota random sampling. Coupons equal to the number of participants were placed in a hat. Ten percent of the coupons were stamped 
and whoever picked the stamped coupon was paid the amount according to his/her choice in line with instructions provided in the experimental task above. The use of coupons placed in a hat provided all the university students who participated in the game with an equal chance to win according to their choices in the task. Selection of ten percent of university students who participated in the experimental task was informed by previous studies. In a Danish study focusing on eliciting risk and time preferences of adult population, only ten percent of the participants were selected and paid for their choices(Andersen et al., 2008). The names of the winners were listed and their contact details collected for administration purposes. The information collected was aggregated for analysis and no information traceable to an individual was used. Payment to the winners was made through e-wallet, a banking platform offered by FNB bank in South Africa. The researcher paid the university students on the days promised according to instructions of the game/task.

Procedure and Data: A total of 85 students (female=48\%) studying a financial literacy module (known as Personal Finance module) at the University of the Free State in South Africa Qwaqwa Campus were conveniently sampled to participate in the study. The high cost of running an experiment and the easy accessibility of university students were the major reasons we settled for a convenient sample. Convenience sampling is a non-probability sampling method suitable for a target population meeting certain criteria, easily accessible, geographical proximity, available at a given time and willing to participate in the study (Etikan, 2016).Students pursuing a Bachelor of commerce degree in the faculty of Economic and Management Sciences were invited to participate in the study on the $28^{\text {th }}$ July 2016 through their emails. The email was send via the university e-learning platform known as blackboard a week before the study was carried out. The target group was 86 undergraduate university students enrolled in a personal finance module. 85 students turned up and the participation rate was $99 \%$. For a population of 100 , assuming a margin of error of $3 \%$, alpha of $1 \%$ and $t=2.58$ a sample of 68 observations can be used for continuous data regression while for a margin of error of $5 \%$, probability of $50 \%$ and a $\mathrm{t}=2.58$, a sample 87 observation can be used for categorical data (Kotrlik \& Higgins, 2001). Sample size observations in our study fell within the required threshold. Participation in the study was voluntary. The study used a questionnaire which included demographic information, financial literacy perceptions, time preferences (a binary choice experimental task) and a financial literacy test. The test was administered before the students studied the financial literacy module.

\section{Results and Findings}

Descriptive statistics: Self-reported evidence from the questionnaire revealed that $49 \%$ of the university students belonged to a household with matric as the highest level of education. These were followed by $32 \%$ of the university students that indicated that they belonged to a household with a degree as the highest level of education. About $56 \%$ of the university students were from households with at least a matric or less. This is a clear indication that the majority of the university students belonged to families with low levels of education. Students answered a total of 20 financial literacy questions which constituted a financial literacy test. The questions were adopted from jumpstart and National Financial Capability Survey (Lusardi \& Mitchell, 2011;Mandell \& Klein, 2009). The average financial literacy score for the group was very low at $43 \%$. The highest and lowest mark scored in the financial literacy test were $65 \%$ and $15 \%$ respectively. A ttest analysis showed no significant difference between male and female university students' level of financial literacy although the average financial literacy level of females was slightly higher. Male participants scored an average of $43 \%$ while female participants scored an average of $44 \%$. This confirmed similar findings in Australia where low financial literacy levels amongst university students was identified(Beal \& Delpachitra, 2003). This shows that the university students under consideration had low levels financial literacy. This is also similar to earlier findings by (Wagland \& Taylor, 2009) who compared performance of university students that received equal treatment across gender and found no difference in performance. In the case under consideration, university students were generally of a similar level of education, under-graduate students pursuing Bachelor of Commerce Degree.

Our results showed a variation in individual time discount rates across gender. In relative terms, female subjects reported higher time discount rates compared to their male counterparts. A t-test analysis on individual discount rates across gender showed a significant difference in the time preferences of female and 
male students at $5 \%$ level of significance (results can be provided on request). In addition, university students with higher financial literacy levels exhibited a higher average time discount rate when compared to those with low levels of financial literacy. On average, female university students reported a higher average individual income and cash equivalence of R798.15 compared to R699.48 for their male counterparts. The average family size for the whole group, males and females, was around five family members. On the other hand, the maximum age recorded for female university students was 40 years compared to 29 years for males. The average ages for male and female university students were 22 and 23 years respectively.

Histograms for elicited time discount rates: Plotted histograms show variations in time discount rates especially across gender and financial literacy level. Figure 1A. shows that male subjects were more willing to accept delayed consumption compared to female subjects. There are lower densities for male subjects for highest discount rates as well as higher densities for lowest discount rates for male subjects in general when compared to female subjects. The discrete and non-negative nature of elicited time discount rates allowed us to make use of the Negative Binomial regression model.

Figure 1: Elicited discount rates
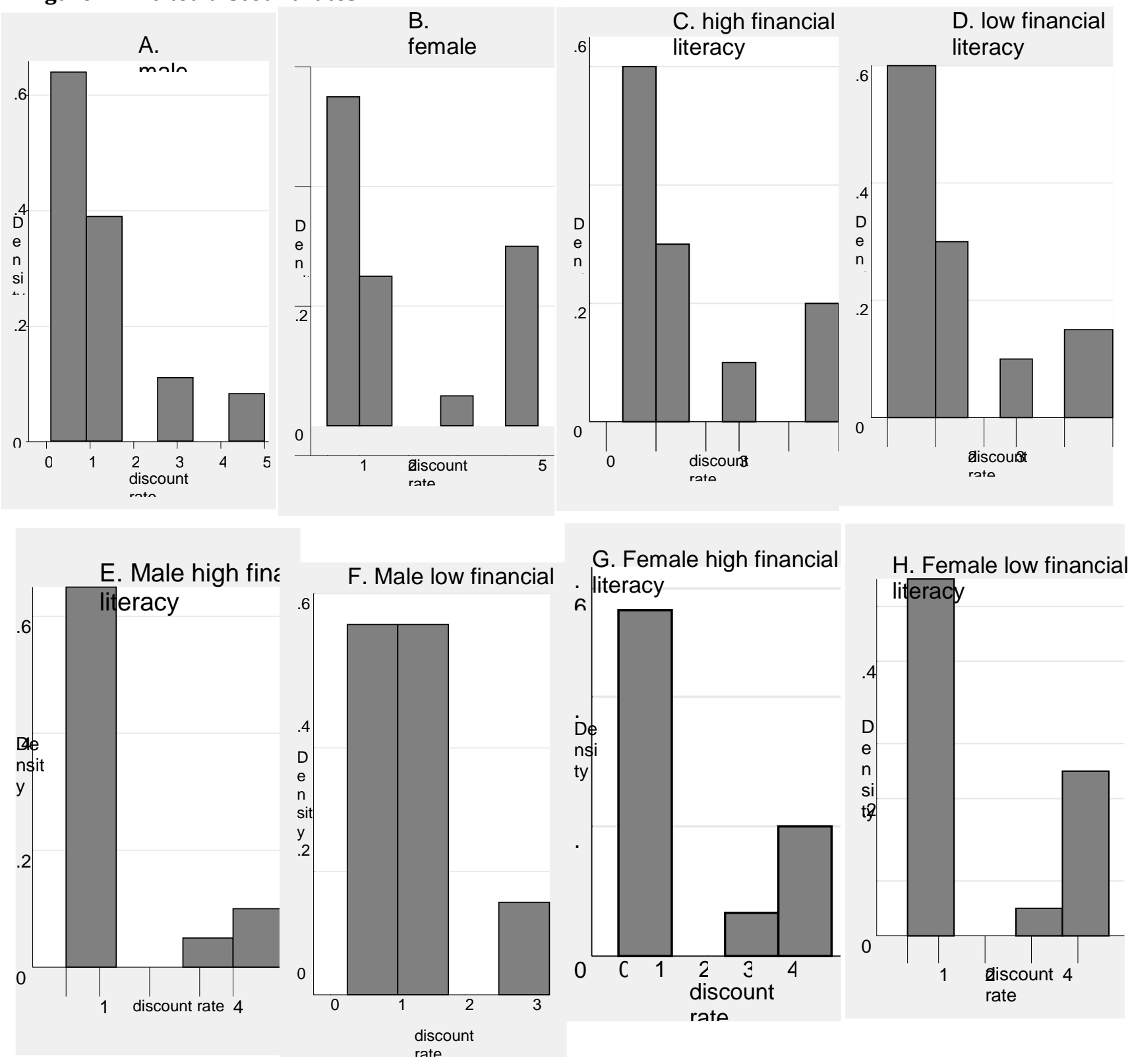
Time Budget: A graphical representation of simple binary choices made by subjects and the equivalent payoff were presented in a time budget (TB) shown in Figure 2. All university students chose optimal choices that maximised their utility subject to the total return they could earn from their choices. In this instance, all university students allocated all the five tokens into two columns. During quota random sampling, most of the subjects were eager to pick the winning coupon, an aspect which revealed their need to maximize their utility. Several researchers have used the Convex Time Budget(CTB) point due to its ease of understanding by subjects, making it an appropriate tool to elicit time preferences (Alan \& Ertac, 2015; Andreoni et al., 2015). The CTB is known to be a better measure of intertemporal choice when compared to the double multiple price list (DMPL) used by Andersen et al. (2008). The corner solution provided by the TB has a predictive power of individual impatience or patience. It also forecasts the demand theory as well as the equality of an individual in allocating income over periods (Andreoni et al., 2015). A marginal rate of substitution of 1.25 shows the opportunity cost of allocating of monetary rewards over the present and future period. It also shows the return the subjects could earn in the event that they were patient enough to receive the pay-off after 6 weeks.

\section{Figure 2: Time Budget}

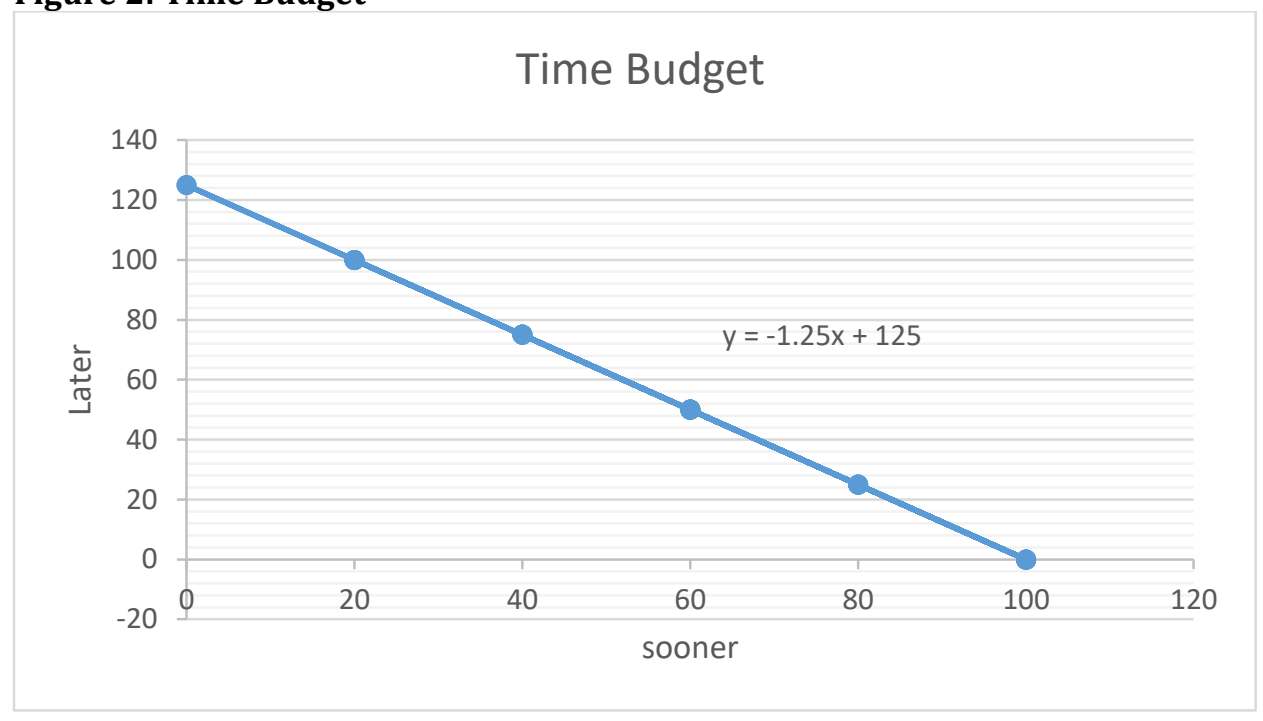

The return for a subject who is patient enough to receive all pay-off after 6 weeks compounded per annum is approximately $217 \%$. This means that subjects who collected all their pay-off in 2 weeks' time had a very high discount rate of the present pay-off. The maximum pay-off a participant could get in two weeks was 100 rands (7.7 USD) if all tokens were allocated in Column A, while those that collected all their pay-off after 6 weeks collected a maximum of 125 rands (9.7 USD) if all the tokens were allocated in Column B. The prevailing exchange rate during the time of the study was 1USD: 12.99 rands.

\section{Regression Analysis}

Time preferences and financial literacy level: Calculated marginal effects in Table 1 show that female university students had a higher individual discount rate compared to their male counterparts. Given that one is female, there is an $0.83 \%$ chance of a higher discount rate compared to male subjects at $5 \%$ level of significance. The first regression confirms that there is a significant variation in individual time discount rates across gender suggesting that female university students were generally impatient. A higher individual time discount rate for female university students compared to their male counterparts might be due gender disparities and girl child challenges regarding financial needs. These findings are contrary to a conclusion reached by Castillo et al., (2011) who found that boys were more impatient than girls in a 2008 study on time preference of high school students in the US. Other variables that significantly influenced time discount rates of all university students under consideration were the highest level of education in the household - matric, diploma or certificate and degree. There is a $2.74 \%, 7.50 \%$ and $3.47 \%$ chance of a high time discount rate for 
a respondent from a household with highest level of education of matric, diploma or certificate and degree respectively.

This reveals that the highest level of education in a household significantly influences respondents' level of patience, which shows an intergenerational education spill over. This confirms findings by (Smith \& Barboza, 2014), who concluded that financial behaviour can be influenced by the parent/guardian's level of education. We split the subjects by their level of financial literacy. An investigation into the university students with high level of financial literacy showed that the time discount rate of university students from households with the highest level of education of a matric, diploma or certificate and degree had a $2.96 \%, 8.4 \%$ and $2.31 \%$ chance of being significantly higher respectively. There was no significant difference between time discount rates of female and male university students with high levels of financial literacy across gender, showing that if both males and females have high levels of financial literacy, their time preferences would not differ significantly. Turning to the regression analysis which focused on university students with low levels of financial literacy, if one is female, there is a $0.96 \%$ chance that one's discount rate will be higher at $5 \%$ level of significance. Female subjects with low levels of financial literacy were found to be impatient. If a respondent was from a household with the highest level of household education of matric, diploma/certificate and degree there was a $1.97 \%, 1.48 \%$ and $2.39 \%$ chance of an increase in time discount rate respectively. Findings suggest that highest level of education in a household influences time preferences of university students in the low financial literacy cohort. Further, there was a $0.07 \%$ significant chance of a decrease in time discount rate if one had low financial literacy as age increased at $10 \%$ level. In a study that looked at time preferences and participation in financial education programs in US, Meier and Sprenger (2013) found that as age increased individual discount rate of participants' decrease. This means that older and low financial literacy university students are more likely to be patient or willing to accept a larger later. This behaviour can be attributed to life experience (Frederick, 2005).

Table 1: Negative Binomial Regression marginal effects: Time discount rate

\begin{tabular}{|c|c|c|c|c|c|c|c|}
\hline & All & all_literate & all_low_lit & high_lit_female & low_lit_female & high_lit_male & low_lit_male \\
\hline female & $\begin{array}{l}0.83^{* *} \\
(0.335)\end{array}$ & $\begin{array}{l}0.50 \\
(0.48)\end{array}$ & $\begin{array}{l}0.96^{* *} \\
(0.420)\end{array}$ & & & & \\
\hline age & $\begin{array}{l}-0.04 \\
(0.045)\end{array}$ & $\begin{array}{l}0.000 \\
(0.097)\end{array}$ & $\begin{array}{l}-0.065^{*} \\
(0.038)\end{array}$ & $\begin{array}{l}-0.048 \\
(0.140)\end{array}$ & $\begin{array}{l}-0.16^{* * *} \\
(0.047)\end{array}$ & $\begin{array}{l}0.041 \\
(0.083)\end{array}$ & $\begin{array}{l}0.022 \\
(0.095)\end{array}$ \\
\hline family_size & $\begin{array}{l}0.095 \\
(0.068)\end{array}$ & $\begin{array}{l}0.094 \\
(0.118)\end{array}$ & $\begin{array}{l}0.077 \\
(0.060)\end{array}$ & $\begin{array}{l}0.088 \\
(0.187)\end{array}$ & $\begin{array}{l}0.066 \\
(0.152)\end{array}$ & $\begin{array}{l}0.20^{\text {** }} \\
(0.092)\end{array}$ & $\begin{array}{l}0.07 \\
(0.048)\end{array}$ \\
\hline matric & $\begin{array}{l}2.74^{* * *} \\
(0.75)\end{array}$ & $\begin{array}{l}2.96^{* * *} \\
(1.115)\end{array}$ & $\begin{array}{l}1.97^{* * *} \\
(0.316)\end{array}$ & $\begin{array}{l}7.02^{* * *} \\
(2.510)\end{array}$ & $\begin{array}{l}3.19 \\
(2.061)\end{array}$ & $\begin{array}{l}0.11 \\
(0.641)\end{array}$ & $\begin{array}{l}1.32 \\
(0.868)\end{array}$ \\
\hline Dip/cert & $\begin{array}{l}7.50^{*} \\
(4.0)\end{array}$ & $\begin{array}{l}8.40^{*} \\
(5.076)\end{array}$ & $\begin{array}{l}1.48^{* *} \\
(0.583)\end{array}$ & $\begin{array}{l}18.99 \\
(1.780)\end{array}$ & $\begin{array}{l}2.71 \\
(5.256)\end{array}$ & $\begin{array}{l}5.79^{* *} \\
(2.768)\end{array}$ & $\begin{array}{l}2.71 \\
(3.066)\end{array}$ \\
\hline degree & $\begin{array}{l}3.47^{\text {**** }} \\
(1.102)\end{array}$ & $\begin{array}{l}2.31^{*} \\
(1.180)\end{array}$ & $\begin{array}{l}2.39^{* * *} \\
(0.417)\end{array}$ & $\begin{array}{l}5.38^{*} \\
(2.81)\end{array}$ & $\begin{array}{l}9.61 \\
(6.440)\end{array}$ & $\begin{array}{l}1.23^{*} \\
(0.643)\end{array}$ & $\begin{array}{l}1.72 \\
(1.881)\end{array}$ \\
\hline lincome & $\begin{array}{l}0.096 \\
(0.156)\end{array}$ & $\begin{array}{l}0.15 \\
(0.210)\end{array}$ & $\begin{array}{l}0.18 \\
(0.187)\end{array}$ & $\begin{array}{l}0.1867 \\
(0.324)\end{array}$ & $\begin{array}{l}0.58^{* *} \\
(0.223)\end{array}$ & $\begin{array}{l}0.58^{\text {*** }} \\
(0.186)\end{array}$ & $\begin{array}{l}0.09 \\
(0.191)\end{array}$ \\
\hline perceptions & $\begin{array}{l}0.35 \\
(0.224)\end{array}$ & $\begin{array}{l}0.030 \\
(0.440)\end{array}$ & $\begin{array}{l}0.30 \\
(0.439)\end{array}$ & $\begin{array}{l}-0.30 \\
(0.845)\end{array}$ & $\begin{array}{l}0.94 \\
(0.609)\end{array}$ & $\begin{array}{l}-0.57 \\
(0.351)\end{array}$ & $\begin{array}{l}0.18 \\
(0.109)\end{array}$ \\
\hline ltest & $\begin{array}{l}0.35 \\
(0.556)\end{array}$ & $\begin{array}{l}-0.557 \\
(1.858)\end{array}$ & $\begin{array}{l}-0.557 \\
(0.726)\end{array}$ & $\begin{array}{l}0.150 \\
(2.757)\end{array}$ & $\begin{array}{l}0.48 \\
(1.600)\end{array}$ & $\begin{array}{l}-4.40^{* * *} \\
(1.517)\end{array}$ & $\begin{array}{l}-1.33^{* * *} \\
(0.500)\end{array}$ \\
\hline$N$ & 85 & 48 & 37 & 24 & 17 & 24 & 20 \\
\hline
\end{tabular}

Standard errors in parentheses

${ }^{*} p<0.10,{ }^{* *} p<0.05,{ }^{* * *} p<0.01$ 
The highest level of education in a household was the only variable that was concluded to be influencing discount rates of female university students with a higher level of financial literacy. The individual time discount rates had a significant chance to increase if the university students were from households with the highest level of education as matric and degree. The discount rates of female university students with low levels of financial literacy had a $0.16 \%$ significant chance to decrease at $1 \%$ level as age increased. This shows that older female university students were more patient, revealing that as one grows older, even if one has low levels of financial literacy, one would have an understanding of the value of money and would be willing to wait to receive a larger later prize. Discount rates of female university students with lower level of financial literacy had a $0.58 \%$ significant chance of increasing at $1 \%$ level as income increased. The finding also confirmed conclusions by Meier and Sprenger (2013), that increase in gross income tends to increase discount rates of subjects. Higher income makes university students in this group impatient. This indicates that female university students with higher income in this cohort were not willing to wait up to six weeks to receive future income (larger later reward), rather, they preferred present consumption.

In cases where the highest level of education in a household was a diploma or certificate, there was a 5.79\% significant chance that time preferences would be higher for male respondents with high level of financial literacy. A $1 \%$ increase in financial literacy test score leads to a $4.4 \%$ significant decrease in time preferences of male university students with higher levels of financial literacy. A higher test score is associated with a lower individual time discount rate for male university students. The findings are similar to what was concluded by Van der Pol (2011) where high levels of financial literacy were associated with lower discount rate for individuals. Further, a $1 \%$ increase in income level is associated with a $0.58 \%$ increase in time discount rate which suggests that university students with high income from this group are generally impatient. In addition, increase in household size for male university students with higher level of financial literacy is associated with a $0.2 \%$ significant increase in time preferences. Meier and Sprenger (2013) also concluded that there was a weak significant impact between number of dependents and time preferences. Large family sizes might have an effect of constraining household resources leading subjects to be impatient. Turning on to male subjects with low financial literacy, a 1\% increase in financial literacy test score leads to a $1.33 \%$ decrease in one's time preferences. In a study on health and preferences Fuchs (1980) also concluded that an increase in knowledge levels is significantly associated with low discount rates. Our findings show that when subjects are split across gender and level of financial literacy, the highest level of education in a household only influence time preferences of subjects with higher levels of financial literacy. The findings submit that for male students, time preferences are influenced by financial literacy. This conclusion could not be confirmed from all female university students. This might imply that financial literacy knowledge influenced time preferences of male university students in this study.

Table 2: Negative Binomial Regression marginal effects: Time discount rate

\begin{tabular}{|c|c|c|c|c|c|c|c|c|}
\hline & All & male & female & Male1 & female1 & all_female & all_male & all1 \\
\hline Ltest_score & $\begin{array}{l}0.11 \\
(0.593)\end{array}$ & $\begin{array}{l}0.04 \\
(0.580)\end{array}$ & $\begin{array}{l}0.12 \\
(1.124)\end{array}$ & $\begin{array}{l}-0.07 \\
(0.539)\end{array}$ & $\begin{array}{l}0.12 \\
(0.560)\end{array}$ & $\begin{array}{l}0.41 \\
(1.064)\end{array}$ & $\begin{array}{l}-0.15 \\
(0.498)\end{array}$ & $\begin{array}{l}0.14 \\
(0.616)\end{array}$ \\
\hline matric & & & & $\begin{array}{l}1.29^{* *} \\
(0.625)\end{array}$ & $\begin{array}{l}2.45^{* * *} \\
(0.195)\end{array}$ & $\begin{array}{l}5.64^{* * *} \\
(1.419)\end{array}$ & $\begin{array}{l}1.45^{* *} \\
(0.723)\end{array}$ & $\begin{array}{l}3.07^{* * *} \\
(0.784)\end{array}$ \\
\hline Dip/cert & & & & $\begin{array}{l}4.96^{*} \\
(2.751)\end{array}$ & $\begin{array}{l}1.57^{* * *} \\
(0.191)\end{array}$ & $\begin{array}{l}7.959^{* *} \\
(3.819)\end{array}$ & $\begin{array}{l}7.19 \\
(4.755)\end{array}$ & $\begin{array}{l}7.12^{* *} \\
(3.357)\end{array}$ \\
\hline degree & & & & $\begin{array}{l}1.71^{* *} \\
(0.725)\end{array}$ & $\begin{array}{l}2.28^{* * *} \\
(0.267)\end{array}$ & $\begin{array}{l}7.559^{* * *} \\
(2.656)\end{array}$ & $\begin{array}{l}2.42^{* * *} \\
(1.21)\end{array}$ & $\begin{array}{l}3.87^{* * *} \\
(1.142)\end{array}$ \\
\hline age & & & & & & $\begin{array}{l}-0.08 \\
(0.064)\end{array}$ & $\begin{array}{l}-0.02 \\
(0.074)\end{array}$ & $\begin{array}{l}-0.02 \\
(0.050)\end{array}$ \\
\hline family_size & & & & & & $\begin{array}{l}0.09 \\
(0.132)\end{array}$ & $\begin{array}{l}0.13^{* *} \\
(0.067)\end{array}$ & $\begin{array}{l}0.09 \\
(0.081)\end{array}$ \\
\hline
\end{tabular}


lincome

perceptions

\subsection{2}

(0.249)

0.35

(0.515)
0.26

0.08

$(0.171)$
0.11

\begin{tabular}{lllllllll}
$\mathrm{N}$ & 85 & 44 & 41 & 44 & 41 & 41 & 44 & 85 \\
\hline
\end{tabular}

Standard errors in parentheses ${ }^{*} p<0.10,{ }^{* *} p<0.05,{ }^{* * *} p<0.01$

Time preferences and financial literacy: We ran a Negative Binomial regression model on time discount rate against financial literacy score for all participants across gender to investigate if there were gender differences in the sample of subjects under consideration. We also controlled for highest level of education in a household, age, family size, income and financial literacy perceptions. The regression analysis on time preference and financial literacy knowledge could not confirm the impact of financial literacy on time discount rates (Table 2). What is evident in all the regression analyses is the significance of highest level of education in a household in influencing time preferences, which shows an intergenerational education spill over. In all cases investigated in Table 2., the highest level of education in a household of matric, diploma/certificate and degree significantly influenced time preferences. The highest level of education in a household tend to increase the chance of a higher time discount rate for participants, showing that the highest level of education in a household increased chances of being impatient on subjects. In a Malaysian study, Sabri et al. (2010) found that discussing family finances with parents increased financial literacy on children. Findings confirm that the respondent's state of the world critically impacts on how they make choices over time. A regression analysis for all males also concluded that time preferences are influenced by family size. A $1 \%$ increase in family sizesignificantly increased time discount rate by $0.13 \%$ chance at $5 \%$ level. This finding also confirms that the state of the world where one lives is important in determining one's intertemporal choices.

Time preferences index: In order to carry out a robust investigation on variables that significantly influenced time preferences and financial literacy jointly, we constructed a time preference index (TPI) by dividing individual time discount rate by the financial literacy test score. The variable represented the individual's intertemporal choice over their financial knowledge. The TPI is a continuous dependent variable which permitted us to run a set of Ordinary Least Square regressions (Table 3). In our first regression analyses, all the university students were included. If one were female, there wasa $0.11 \%$ chance that their time discount rate would be significantly higher at $5 \%$ level of significance. This was a confirmation that gender differences significantly influence time preference choices given an individual's financial literacy level. A study on young Australians confirmed a significant variation of patience levels across gender (Booth \& Katic, 2013). The highest level of education in a household significantly influence TPI variable. Individuals who indicated that they belonged to a household with the highest level of education as matric, certificate/diploma and degree significantly increased the TPI variable by $0.16 \%, 0.21 \%$ and $0.18 \%$ chance respectively, showing that intergenerational education significantly influence intertemporal choices. Further, a $1 \%$ increase in a test score led to $0.55 \%$ decrease in the TPI variable, showing that financial literacy significantly influences time preferences.

According to our results, increase in financial literacy increased patience amongst university students, a trait which is important for an individual to earn a higher return from time preference choices. In the high financial literacy group, the highest level of education in a household which significantly influence the TPI variable were matric and Diploma/certificate. At higher levels of financial literacy, gender difference did not significantly influence TPI variable confirming findings from Table 1. These findings show that if both female and male university students attained higher levels of financial literacy, the TPI variable will not be significantly different. A regression analysis of all university students with low financial literacy indicated that gender differences weakly significantly influenced TPI variable at 10\%. At low levels of financial literacy, gender differences were prevalent. If one were a female with low levels of financial literacy, there was a $0.17 \%$ chance that the TPI variable would be higher. Another variable that influenced TPI variable at low levels of financial literacy was the highest level of education in a household of degree. Only highest level of education in household of matric significantly influenced TPI variable for female university students with 
higher levels of financial literacy. If one were a female with higher level of financial literacy, there would be a $0.31 \%$ significant chance that the TPI variable would be higher if they belonged to a household with highest level of education of matric. For female subjects with lower levels of financial literacy, as age increased TPI variable significantly decreased by $0.041 \%$ at $5 \%$ level, a finding which confirmed the impact of age on financial experience indicated by Frederick (2005). Highest level of education in a household of diploma/certificate significantly influenced TPI variable with a $0.31 \%$ significant chance of increasing TPI for male university students with higher levels of financial literacy. An increase in financial literacy increased patience levels among male university students categorised by financial literacy level.

Financial literacy weakly significantly influenced TPI for male subjects with high and low level of financial literacy. When university students were split into males and females with lower or higher levels of financial literacy, only the highest level of education in a household significantly influenced TPI variable for university students with higher levels of financial literacy, a finding also highlighted in table 1 , showing that the highest level of education in a household significantly impacts time preferences of university students with high financial literacy levels. The findings are in line with findings by Sabri et al. (2010), who indicated in a Malaysian study that students who received financial literacy from their parents were found to be financially literate. The study concluded that the highest level of household education causes university students to be impatient, since their time discount rates are more likely to increase. The ordinary least squares regression analysis shows that increase in financial literacy generally makes university studentspatient. Other variables that were concluded to influence time preferences were income, age and family size.

Table 3: OLS Regression: Time preference index marginal effect

\begin{tabular}{|c|c|c|c|c|c|c|c|}
\hline & All & all_literate & all_low_lit & highlit_female & lowlit_female & high_lit_male & low_lit_male \\
\hline female & $\begin{array}{l}0.11^{* *} \\
(0.054)\end{array}$ & $\begin{array}{l}0.047 \\
(0.060)\end{array}$ & $\begin{array}{l}0.17^{*} \\
(0.101)\end{array}$ & & & & \\
\hline test & $\begin{array}{l}-0.55^{* *} \\
(0.262)\end{array}$ & $\begin{array}{l}-0.38 \\
(0.375)\end{array}$ & $\begin{array}{l}-1.08 \\
(0.843)\end{array}$ & $\begin{array}{l}-0.26 \\
(0.597)\end{array}$ & $\begin{array}{l}-1.03 \\
(1.714)\end{array}$ & $\begin{array}{l}-0.81^{*} \\
(0.461)\end{array}$ & $\begin{array}{l}-1.73^{*} \\
(0.810)\end{array}$ \\
\hline age & $\begin{array}{c}-0.0063 \\
(0.007)\end{array}$ & $\begin{array}{l}0.0013 \\
(0.011)\end{array}$ & $\begin{array}{l}-0.014 \\
(0.011)\end{array}$ & $\begin{array}{c}-0.0023 \\
(0.017)\end{array}$ & $\begin{array}{l}-0.041^{* *} \\
(0.014)\end{array}$ & $\begin{array}{r}-0.0019 \\
(0.013)\end{array}$ & $\begin{array}{c}-0.0013 \\
(0.022)\end{array}$ \\
\hline Family size & $\begin{array}{l}0.017 \\
(0.013)\end{array}$ & $\begin{array}{l}0.0086 \\
(0.013)\end{array}$ & $\begin{array}{l}0.026 \\
(0.020)\end{array}$ & $\begin{array}{l}0.0095 \\
(0.027)\end{array}$ & $\begin{array}{l}0.036 \\
(0.048)\end{array}$ & $\begin{array}{l}0.017 \\
(0.016)\end{array}$ & $\begin{array}{l}0.013 \\
(0.017)\end{array}$ \\
\hline matric & $\begin{array}{l}0.16^{* * *} \\
(0.053)\end{array}$ & $\begin{array}{l}0.15^{* *} \\
(0.058)\end{array}$ & $\begin{array}{l}0.14 \\
(0.108)\end{array}$ & $\begin{array}{l}0.31^{* *} \\
(0.134)\end{array}$ & $\begin{array}{l}0.074 \\
(0.249)\end{array}$ & $\begin{array}{l}0.021 \\
(0.053)\end{array}$ & $\begin{array}{l}-0.0082 \\
(0.221)\end{array}$ \\
\hline diploma & $\begin{array}{l}0.21^{* *} \\
(0.086)\end{array}$ & $\begin{array}{l}0.23^{* *} \\
(0.113)\end{array}$ & $\begin{array}{l}0.099 \\
(0.122)\end{array}$ & $\begin{array}{l}0.15 \\
(0.172)\end{array}$ & $\begin{array}{l}-0.14 \\
(0.452)\end{array}$ & $\begin{array}{l}0.31^{* *} \\
(0.124)\end{array}$ & $\begin{array}{l}-0.0098 \\
(0.223)\end{array}$ \\
\hline degree & $\begin{array}{l}0.18^{* * *} \\
(0.058)\end{array}$ & $\begin{array}{l}0.088 \\
(0.053)\end{array}$ & $\begin{array}{l}0.26^{*} \\
(0.144)\end{array}$ & $\begin{array}{l}0.15 \\
(0.113)\end{array}$ & $\begin{array}{l}0.42 \\
(0.323)\end{array}$ & $\begin{array}{l}0.077 \\
(0.051)\end{array}$ & $\begin{array}{l}-0.052 \\
(0.260)\end{array}$ \\
\hline income & $\begin{array}{l}0.0097 \\
(0.022)\end{array}$ & $\begin{array}{l}0.013 \\
(0.031)\end{array}$ & $\begin{array}{l}0.022 \\
(0.045)\end{array}$ & $\begin{array}{l}0.016 \\
(0.048)\end{array}$ & $\begin{array}{l}0.16^{*} \\
(0.084)\end{array}$ & $\begin{array}{l}0.054 \\
(0.045)\end{array}$ & $\begin{array}{l}-0.013 \\
(0.058)\end{array}$ \\
\hline perceptions & $\begin{array}{l}0.063^{*} \\
(0.036)\end{array}$ & $\begin{array}{l}0.0074 \\
(0.057)\end{array}$ & $\begin{array}{l}0.075 \\
(0.056)\end{array}$ & $\begin{array}{l}-0.026 \\
(0.122)\end{array}$ & $\begin{array}{l}0.22 \\
(0.136)\end{array}$ & $\begin{array}{l}-0.053 \\
(0.060)\end{array}$ & $\begin{array}{l}0.028 \\
(0.043)\end{array}$ \\
\hline$N$ & 85 & 48 & 37 & 24 & 17 & 24 & 20 \\
\hline$R^{2}$ & 0.192 & 0.153 & 0.312 & 0.199 & 0.456 & 0.446 & 0.472 \\
\hline
\end{tabular}

Standard errors in parentheses ${ }^{*} p<0.10,{ }^{* *} p<0.05,{ }^{* * *} p<0.01$

\section{Conclusion}

This study used a questionnaire that included a simple binary experimental game of tokens(toelicit time preferences of subjects) and a financial literacy test.Time discount rates of categoriseduniversity students 
with higher or lower financial literacy levels weresignificantly influenced by the household's highest level of education and gender differences.When subjects were split according to gender and literacy levels, the highest level of education in a household only influenced subjects with higher levels of financial literacy. These findingsreveal that highest level of education in ahousehold significantly influence time preference choices of individuals, showing the effect of education externality across generations. Elicited time discount rates from the experimental game also show that female university students' time discount rates were more likely to be higher than those of their male counterparts - reflecting that females under considerationwere more impatient especially if they belong to a low financial literacy level group. Our findingsreveal that gender differences impact time preferences, especially after factoring financial literacy level. This may be explained by the different financial challenges faced by the girl child. Providing financial literacy to university students can play an important role in reducing time preference differences across gender. The study shows that financial literacy significantly impacts time preferences of male subjects with low and high levels of financial literacy. As financial literacy increases, male university students are more likely to be patient. Being patient is a trait associated with waiting longer to earn a larger later reward with a high return. Increasing financial literacy to male university students will help to improve their welfare.

A robust check using the OLS model on time preference index (TPI) variable confirmed that the highest level of education in a household significantly influences time preferences of subjects, especially students with higher level of financial literacy, showing that education has a generational spill over effect. Providing education to the current generation will impact the welfare of future generations. The OLS regression model for the whole group also showed that financial literacy significantly influenced university students' time preferences. Increasing financial literacy amongst university students induces them to be patient. Our study shows that provision of financial literacy to university students will improve their welfare by impacting their time preferences. Other variables concluded to significantly influence university students' time preferences were age, income and family size. It is critical to understand how time preferences of individuals are formulated as they influence perseverance and patience which are vital for future welfare and investment choices. The findings are however not exhaustive; a deeper investigation into how household levels of education influence time preferences is required. The list of independent variables can be stretched to include more characteristics. More so, factors that tend to increase time discount rates for female university students need further exploration. It will be important to understand how university students react to high and low time preference incentives at varying time stretches. Further research may investigate whether time preferences change as the level of income changes.

\section{References}

Adan, A. \& Natale, V. (2002). Gender differences in morningness-eveningness preference. Chronobiology International, 19(4), 709-720. https://doi.org/10.1081/CBI-120005390

Ajzen, I. (2011). The theory of planned behaviour: Reactions and reflections. Psychology \& Health, 26(9), 1113-1127. https://doi.org/10.1080/08870446.2011.613995

Alan, S. \& Ertac, S. (2015). Patience, self-control and the demand for commitment: Evidence from a large-scale field experiment. Journal of Economic Behavior \& Organization, 115, 111-122.

Andersen, S., Harrison, G. W., Lau, M. I. \& Rutström, E. E. (2006). Elicitation using multiple price list formats. Experimental Economics, 9(4), 383-405.

Andersen, S., Harrison, G. W., Lau, M. I. \& Rutström, E. E. (2008). Eliciting risk and time preferences. Econometrica, 76(3), 583-618. Retrieved from http://onlinelibrary.wiley.com/doi/10.1111/j.14680262.2008.00848.x/abstract

Andreoni, J., Kuhn, M. A. \& Sprenger, C. (2015). Measuring time preferences: A comparison of experimental methods. Journal of Economic Behavior \& Organization, 116, 451-464. https://doi.org/10.1016/j.jebo.2015.05.018

Andreoni, J. \& Sprenger, C. (2012). Estimating Time Prefernces from Convex Budgets. American Economic Review, 102(7), 3333-3356. https://doi.org/10.1257/aer.102.7.3333

Angerer, S., Lergetporer, P., Glätzle-Rützler, D. \& Sutter, M. (2015). How to measure time preferences in children: a comparison of two methods. Journal of the Economic Science Association, 1(2), 158-169. https://doi.org/10.1007/s40881-015-0016-0

Argent, J., Finn, A., Leibbrandt, M. \& Woolard, I. (2009). Poverty: Analysis of the NIDS Wave 1 dataset. National 
Income Dynamics Study, NiDS Discussion Paper, (12).

Ariely, D., Loewenstein, G. \& Prelec, D. (2003). Coherent arbitrariness: Stable demand curves without stable preferences. The Quarterly Journal of Economics, 118(1), 73-106. Retrieved from http://qje.oxfordjournals.org/content/118/1/73.short

Ariely, D.\& Wertenbroch, K. (2002). Procrastination, Deadlines, and Performance: Self-Control by Precommitment. Psychological Science, 13(3), 219-224. Retrieved from http://pss.sagepub.com/content/13/3/219.short4

Ausubel, L. M. (1999). Adverse Selection in the Credit Card Market, (C), 1-52. Retrieved from http://weber.ucsd.edu/ aronatas/conference/adverse.pdf

Bajtelsmit, V. (1999). Gender differences in defined contribution pension decisions. Financial Services Review, 8(1), 1-10. https://doi.org/10.1016/S1057-0810(99)00030-X

Banks, J., o'Dea, C.\& Oldfield, Z. (2010). Cognitive Function, Numeracy and Retirement Saving Trajectories. The Economic Journal, 120(548), F381-F410. Retrieved from http://onlinelibrary.wiley.com/doi/10.1111/j.1468-0297.2010.02395.x/pdf

Batty, M., Collins, J.\& Odders-White, E. (2015). Experimental Evidence on the Effects of Financial Education on Elementary School Students' Knowledge, Behavior, and Attitudes. Journal of Consumer Affairs, 49(1), 69-96. Retrieved from http://onlinelibrary.wiley.com/doi/10.1111/joca.12058/full

Beal, D. J.\& Delpachitra, S. B. (2003). Financial Literacy Among Australian University Students.Centre for Australian Financial Institutions (CAFI) at the University of Southern Queensland, 1-15. https://doi.org/10.1111/j.1759-3441.2003.tb00337.x

Becchetti, L., Caiazza, S.\& Coviello, D. (2013). Financial education and investment attitudes in high schools: evidence from a randomized experiment. Applied Financial Economics, 23(10), 817-836.

Benjamin, D. J., Brown, S. A.\& Shapiro, J. M. (2013). WHO is "behavioral"? Cognitive ability and anomalous preferences. Journal of the European Economic Association, 11(6), 1231-1255. https://doi.org/10.1111/jeea.12055

Benzion, U., Rapoport, A.\& Yagil, J. (1989). Discount rates inferred from decisions: An experimental study. Management Science, 35(3), 270-284. $\quad$ Retrieved from http://pubsonline.informs.org/doi/abs/10.1287/mnsc.35.3.270

Bernheim, B. D., Garrett, D. M.\& Maki, D. M. (2001). Education and saving:: The long-term effects of high school financial curriculum mandates. Journal of Public Economics, 80(3), 435-465. Retrieved from http://www.sciencedirect.com/science/article/pii/S0047272700001201

Booth, A. L.\& Katic, P. (2013). Cognitive Skills, Gender and Risk Preferences. Economic Record, 88(284), 1930. https://doi.org/10.1111/1475-4932.12014

Capuano, A.\& Ramsay, I. (2011). What causes suboptimal financial behaviour? An exploration of financial literacy, social influences and behavioural economics. An Exploration of Financial Literacy, Social Influences and Behavioural Economics (March 23, 2011). U of Melbourne Legal Studies Research Paper, (540). Retrieved from http://papers.ssrn.com/sol3/papers.cfm?abstract_id=1793502

Carlin, B. I.\& Robinson, D. T. (2010). What Does Financial Literacy Training Teach Us? https://doi.org/http://www.nber.org/papers/w16271.pdf

Castillo, M., Ferraro, P. J., Jordan, J. L.\& Petrie, R. (2011). The today and tomorrow of kids: Time preferences and educational outcomes of children. Journal of Public Economics, 95(11), 1377-1385. Retrieved from http://www.sciencedirect.com/science/article/pii/S0047272711001381

Chabris, C. F., Laibson, D., Morris, C. L., Schuldt, J. P.\& Taubinsky, D. (2008). Individual laboratory-measured discount rates predict field behavior. Journal of Risk and Uncertainty, 37(2-3), 237-269. Retrieved from http://link.springer.com/article/10.1007/s11166-008-9053-x

Charness, G.\& Gneezy, U. (2012). Strong Evidence for Gender Differences in Risk Taking. Journal of Economic Behavior and Organization, 83(1), 50-58. https://doi.org/10.1016/j.jebo.2011.06.007

Charness, G., Gneezy, U.\& Imas, A. (2013). Experimental methods: Eliciting risk preferences. Journal of Economic Behavior \& Organization, 87, 43-51. Retrieved from http://www.sciencedirect.com/science/article/pii/S016726811200282X

Chen, H.\& Volpe, R. P. (1998). An analysis of personal financial literacy among college students. Financial Services $\quad$ Review, 7(2), 107-128. $\quad$ Retrieved from http://www.sciencedirect.com/science/article/pii/S1057081099800067

Croson, R.\& Gneezy, U. (2009). Gender Differences in Preferences. Journal of Economic Literature, 47(2), 448474. https://doi.org/10.1257/jel.47.2.448 
Cull, M.\& Whitton, D. (2011). University Students' Financial Literacy Levels: Obstacles and Aids. Economic and Labour Relations Review, 22(1), 99-114. https://doi.org/http://search.informit.com.au/browseJournalTitle;res=IELBUS;issn=1035-3046

DellaVigna, S. (2009). Psychology and Economics: Evidence from the Field. Journal of Economic Literature, 47(2), 315-372. Retrieved from http://www.ingentaconnect.com/content/aea/jel/2009/00000047/00000002/art00001

Eckel, C. C. \& Grossman, P. J. (2008). Men, Women and Risk Aversion: Experimental Evidence. Handbook of experimental economics results, McGraw-Hill, New York. https://doi.org/10.1016/S15740722(07)00113-8

Epper, T., Fehr-Duda, H.\& Bruhin, A. (2009). Uncertainty Breeds Decreasing Impatience: The Role of Risk Preferences in Time Discounting Uncertainty Breeds Decreasing Impatience: The Role of Risk Preferences in Time Discounting. University of Zurich Working Paper, 412(412). https://doi.org/10.2139/ssrn.1416007

Etikan, I. (2016). Comparison of Convenience Sampling and Purposive Sampling. American Journal of Theoretical and Applied Statistics, 5(1), 1. https://doi.org/10.11648/j.ajtas.20160501.11

Frederick, S. (2005). Cognitive Reflection and Decision Making. Journal of Economic Perspectives, 19(4), 2542. https://doi.org/10.1257/089533005775196732

Frederick, S., Loewenstein, G.\& Donoghue, T. O. (2007). Time Discounting and Time Preference : A Critical Review. Journal of Economic Literature, 40(2), 351-401. Retrieved from http://www.jstor.org/stable/2698382

Frederick, S., Loewenstein, G.\& O'donoghue, T. (2002). Time Discounting and Time Preference: A Critical Review. Journal of Economic Literature, 40(2), 351-401. https://doi.org/10.1257/jel.40.2.351

Fuchs, V. (1980). Time Preference and Health: An Exploratory Study. https://doi.org/10.3386/w0539

Gallery, N., Newton, C.\& Palm, C. (2011). Framework for assessing financial literacy and superannuation investment choice decisions. Australasian Accounting, Business and Finance Journal, 5(2), 3-22. Retrieved

from http://search.proquest.com/openview/8e76d19fc343a195363e67d46d82d982/1?pqorigsite $=$ gscholar\&cbl $=38872$

Giné, X., Goldberg, J., Silverman, D.\& Yang, D. (2011). Revising Commitments: Time Preference and Time Inconsistency in the Field. Working Paper. Retrieved from http://cega.berkeley.edu/assets/cega_events/17/Revising_Commitments_Time_Preference_and_Time_Inconsistency_in_the_Field.pdf

Güth, W. (2004). Time and Decision: Economic and Psychological Perspectives on Intertemporal Choice. The Journal of Socio-Economics, 33(4), 519-521. https://doi.org/10.1016/j.socec.2004.04.003

Hilmer, C.E.\& Hilmer, M. J. (2014). Practical econometrics. data collection, analysis and application.McGrallHill, New York. https://doi.org/9780071318518

Hoch, S. J.\& Loewenstein, G. F. (1991). Time-inconsistent preferences and consumer self-control. Journal of Consumer Research, 4, 492-507. Retrieved from http://www.jstor.org/stable/2626842

Huston, S. J. (2010). Measuring financial literacy. Journal of Consumer Affairs, 44(2), 296-316. Retrieved from http://onlinelibrary.wiley.com/doi/10.1111/j.1745-6606.2010.01170.x/full

Imrohoroglu, A., Imrohoroglu, S.\& Joines, D. H. (2003). Time-Inconsistent Preferences and Social Security. The Quarterly Journal of Economics, 118(2), 745-784. https://doi.org/10.1162/003355303321675509

Kennedy, B. P. (2013). The theory of planned behavior and financial literacy: A predictive model for credit card debt? ProQuest Dissertations and Theses, 84. https://doi.org/Paper 480

Kim, S., Dueker, G. L., Hasher, L.\& Goldstein, D. (2002). Children's time of day preference: Age, gender and ethnic differences. Personality and Individual Differences, 33(7), 1083-1090. https://doi.org/10.1016/S0191-8869(01)00214-8

Kotrlik, J.\& Higgins, C. (2001). Organizational research: Determining appropriate sample size in survey research appropriate sample size in survey research. Information Technology, Learning, and Performance Journal, 19(1), 43. https://doi.org/10.1109/LPT.2009.2020494

LaBorde, P. M.\& Mottner, S. W. (2013). Personal Financial Literacy: Perceptions of Knowledge, Actual Knowledge and Behavior of College Students. Journal of Financial Education, 39(3/4), 1-30. Retrieved from http://www.jstor.org/stable/23608645

Lawrance, E. (1991). Poverty and the rate of time preference: evidence from panel data. Journal of Political Economy. Retrieved from http://www.journals.uchicago.edu/doi/abs/10.1086/261740 
Loewenstein, G., Read, D.\& Baumeister, R. F. (2003). Time and Decision: Economic and Psychological Perspectives of Intertemporal Choice. Russell Sage Foundation, New York.

Loewenstein, G.\& Thaler, R. H. (1989). Anomalies: intertemporal choice. The Journal of Economic Perspectives, 3(4), 181-193. Retrieved from http://www.jstor.org/stable/1942918

Lusardi, A.\& Mitchell, O. S. (2005). Financial literacy and planning: Implications for retirement wellbeing. Michigan Retirement Research Center Research Paper No. WP, 108. Retrieved from http://papers.ssrn.com/sol3/papers.cfm?abstract_id=881847

Lusardi, A.\& Mitchell, O. S. (2011). Financial literacy around the world: an overview. Journal of Pension Economics and Finance, 10(4), 497-508. Retrieved from http://journals.cambridge.org/abstract_S1474747211000448

Lusardi, A., Mitchell, O. S.\& Curto, V. (2010). Financial literacy among the young. Journal of Consumer Affairs, $44(2), \quad 358-380 . \quad$ Retrieved from http://onlinelibrary.wiley.com/doi/10.1111/j.17456606.2010.01173.x/full

Mandell, L. (2008). Financial education in high school. Overcoming the Saving Slump: How to Increase the Effectiveness of Financial Education and Saving Programs, 257-279. Retrieved from http://books.google.co.za/books?hl=en\&lr=\&id=1M3RUvoG614C\&oi=fnd\&pg=PA257\&dq=Financial+ literacy,+Boyce,+Danes+(2004)+\&ots=v4D100bhXV\&sig=G-2wRq_GrPZba9ZA44yagKMp7oY

Mandell, L.\& Klein, L. S. (2009). The Impact of Financial Literacy Education on Subsequent Financial Behavior. Journal of Financial Counseling \& Planning, 20(1), 15-24. Retrieved from http://search.ebscohost.com/login.aspx?direct=true\&db=bth\&AN=43915999\&site=ehost-live

Mas-Colell, A., Whinston, M. D., \& Green, J. R. (1995). The principal-agent problem,". Microeconomic Theory, 447-510. Oxford University Press, Oxford.

Meier, S.\& Sprenger, C. D. (2013). Discounting financial literacy: Time preferences and participation in financial education programs. Journal of Economic Behavior \& Organization, 95, 159-174. Retrieved from http://www.sciencedirect.com/science/article/pii/S0167268112000625

Mitchell, 0. S. (2009). Financial Literacy Among the Young.Journal of Consumer Affairs, 44(2), 358-380. Retrieved from http://onlinelibrary.wiley.com/doi/10.1111/j.1745-6606.2010.01173.x/full

Németh, K. H. D. B. (2014). An Empirical Study of Financial Literacy versus Risk Tolerance Among Higher Education Students. Public Finance Quarterly,4, 445. Retrieved from http://www.asz.hu/publicfinance-quarterly-articles/2014/an-empirical-study-of-financial-literacy-versus-risk-toleranceamong-higher-education-students/a-huzdik-beres-nemeth-2014-4.pdf

Norum, P. (2008). The role of time preference and credit card usage in compulsive buying behaviour. International Journal of Consumer Studies, 32(3), 269-275. Retrieved from http://onlinelibrary.wiley.com/doi/10.1111/j.1470-6431.2008.00678.x/full

Oanea, D. C.\& Dornean, A. (2012). Defining and Measuring Financial Literacy. New Evidence from Romanian' Students of the Master in Finance. Annals of the Alexandru Ioan Cuza University - Economics, 59(2), 113-129. https://doi.org/10.2478/v10316-012-0036-3

Parker, A. M.\& Fischhoff, B. (2005). Decision-making competence: External validation through an individualdifferences approach. Journal of Behavioral Decision Making, 18(1), 1-27. https://doi.org/10.1002/bdm.481

Powell, M.\& Ansic, D. (1997). Gender differences in risk behaviour in financial decision making, an experiment analysis. Journal of Economic Psychology, 18(6), 605-628. https://doi.org/10.1016/S0167-4870(97)00026-3

Rabin, M. (2002). A perspective on psychology and economics. European Economic Review, 46(4), 657-685. Retrieved from http://www.sciencedirect.com/science/article/pii/S0014292101002070

Rae, J.\& Mixter, C. W. (1905). The sociological theory of capital. Macmillan Company.

Sabri, M. F., MacDonald, M., Hira, T. K.\& Masud, J. (2010). Childhood Consumer Experience and the Financial Literacy of College Students in Malaysia. Family \& Consumer Sciences Research Journal, 38(4), 455467. https://doi.org/10.1111/j.1552-3934.2010.00038.x

Sayinzoga, A., Bulte, E. H.\& Lensink, R. (2016). Financial Literacy and Financial Behaviour: Experimental Evidence from Rural Rwanda. Economic Journal, 126(594), 1571-1599. https://doi.org/10.1111/ecoj.12217

Schagen, S.\& Lines, A. (1996). Financial literacy in adult life: a report to the Natwest Group Charitable Trust. NFER. Retrieved from https://www.nfer.ac.uk/publications/91091/91091.pdf

Shambare, R.\& Rugimbana, R. (2012). Financial Literacy Among the Educated: An Exploratory Study of 
Selected University Students in South Africa By. Feature Article, 4425(4), 581-590. https://doi.org/10.1002/tie

Smith, C.\& Barboza, G. (2014). The Role of Trans-Generational Financial Knowledge and Self-Reported Financial Literacy on Borrowing Practices and Debt Accumulation of College Students. Journal of Personal Finance, $13(2), \quad 28 . \quad$ Retrieved from http://search.proquest.com/openview/5c7378f8f8e46cd7d823ba9e979975aa/1?pqorigsite $=$ gscholar

Tang, N.\& Peter, P. C. (2015). Financial knowledge acquisition among the young: The role of financial education, financial experience, and parents' financial experience. Financial Services Review, 24(2), 119.

Retrieved

from http://search.proquest.com/openview/ba4d2750e5e4c38a618e0fa26ece9a1a/1?pqorigsite=gscholar

Van der Pol, M. (2011). Health, education and time preference. Health Economics, 20(8), 917-929. https://doi.org/http://dx.doi.org/10.1002/hec.1655

Wagland, S. P.\& Taylor, S. (2009). When it comes to financial literacy, is gender really an issue? Australasian Accounting, Business and Finance Journal, 3(1), 3. Retrieved from http://ro.uow.edu.au/aabfj/vol3/iss1/3/

Ethical considerations: Permission to carry out the study was granted by the University of the Free State Ethics Committee (Number: UFS-HSD2016/0079). Participation in the experiment was voluntary and students were allowed to stop participating in the experiment at any time. The participants were made aware of the purpose of the study. 